\title{
Geoculture and unevenness: Occidentalism in the history of uneven and combined development
}

\author{
Joseph Leigh
}

To cite this article: Joseph Leigh (2020): Geoculture and unevenness: Occidentalism in the history of uneven and combined development, Cambridge Review of International Affairs, DOI: 10.1080/09557571.2020.1820953

To link to this article: https://doi.org/10.1080/09557571.2020.1820953
(c) 2020 The Author(s). Published by Informa UK Limited, trading as Taylor \& Francis Group

曲 Published online: 24 Sep 2020.

Submit your article to this journal

LII Article views: 212

Q View related articles $₫$

View Crossmark data $\asymp$ 


\title{
Geoculture and unevenness: Occidentalism in the history of uneven and combined development
}

\author{
Joseph Leigh \\ London School of Economics and Political Science
}

\begin{abstract}
Recent works on 'uneven and combined development' (UCD) have focused on its contributions to the study of political economy and geopolitics, but they have yet to systematically address the cultural dimension of social change - the socially shared ideas by which people understand and act upon the world. The present article addresses this lacuna by applying the premises of UCD to the nineteenth-century emergence of Occidentalism: the idea of 'the West' as the dominant site of culture, civilisation and modernity. Against the problems of methodological internalism and Eurocentrism, I argue that the categories of unevenness and combined development provide critical entry points for an examination of the international construction of 'Western' identities and discourses during the late-nineteenth century imperial era. Specifically, I advance a theory of geocultural feedback which locates the constituting terms of those identities and discourses in a specific conjuncture of global unevenness: how the experience of 'relative backwardness' in late-industrialising societies translated into self-consciously 'Westernising' projects of catch-up development which destabilised prevailing conceptions of white European supremacy. In both the British and American empires, this historical dynamic produced a distinct pattern of cultural transformation: a reactive discourse of civilisational closure centred on the defence of 'the West.'
\end{abstract}

\section{Introduction: the logic of culture and the logic of the international}

Transportation has become so convenient these days that once the wind of Western civilisation blows to the East, every blade of grass and every tree in the East follow what the Western wind brings.

—Fukazawa Yukichi, 'Goodbye Asia,' 1885 ([1885] 2015, 351)

In nineteenth-century Asia, the image of 'Western civilisation' was a central part of efforts to meet the challenge of global modernity (Aydin 2007). The idea of a culturally and politically distinctive 'Western world,' a notion that did not exist in any systematic form prior to the 1870s (Bonnett 2017; GoGwilt 1995), now became a central marker of 'progress,' 'culture' and 'civilisation' - a repertoire of terms which expressed the widely-felt imbalances of an emergent

\footnotetext{
I am especially grateful to my supervisor, George Lawson, for his advice and support throughout the $\mathrm{PhD}$ from which this article arises. Thanks also to Justin Rosenberg, the editors of CRIA, and three anonymous reviewers for convening this special issue and providing invaluable comments and suggestions. I would also like to thank Grace Benton and Lewis Bassett-Yerrell for their insightful comments on an earlier draft.
} 
international order (Zarakol 2011, 54). To envision Asia's 'Westernisation' was thus to think globally about differentials of power and prestige that were novel yet inexorable features of the evolving industrial period (Osterhammel 2014, 87). It was to engage, fundamentally, in a global transformation of cultural life with the international relations of power and difference at its heart.

Yet, among the keywords of modern social science, few terms have been so routinely and consistently associated with the 'internal history of society' as that of culture (Tenbruck 1994). The inherited conceptual pairing of 'national identity' and 'national culture,' forged during the nineteenth century (Goswami 2002), provides a concrete illustration of this prevalent conceptual framing: the idea of 'the cultural' as a purely endogenous social space, often virtually synonymous with the identities and symbols of a bounded national homeland (cf. Gilroy 1993, 2-5). This domestication of culture reflects, in part, the methodological nationalism of much contemporary social science, that is, its tendency to identify the nation-state as the default unit of social analysis and thereby occlude the international, geopolitical, and intersocietal dimensions of social change (Wimmer and Schiller 2003; Beck 2007). More generally, however, it is best understood as an expression of methodological internalism: the assumption, inherited from the conceptual models of classical sociology and anthropology, that all social phenomena can be explained by reference to the endogenous features of a given society or form of civilisation (Rosenberg 2006). Articulated perhaps most clearly in Weber's sociology of world religions, this internalist schema treats cultural systems as historically and territorially discrete units of comparison, obscuring the ways international, global and geopolitical processes help structure the production of collective identities (Weber 1991, Part III). From the same internalist premise, Durkheim conceived domestic social structures as the determinant of social value systems and religious beliefs, locating the drivers of cultural development within a territorially bounded 'national life' (Durkheim 2008, 315-17, 322). On a similar basis, LéviStrauss defined the task of structural anthropology as the analysis of a society's endogenous symbolic systems through the comparative study of distinct national or tribal orders (Lévi-Strauss 1963, 296). ${ }^{1}$ As these examples illustrate, the tacit framework of methodological internalism has exercised a deep influence on the development of modern social science. While such intrinsically intersocietal processes as conquest, trade, and intellectual exchange have profoundly shaped the history of culture and ideas (Barkawi and Lawson 2017), their significance has rarely been incorporated into any formal theorisation of sociocultural development. Rather, scholars of International Relations (IR) have tended to import their theories of culture from sociology and anthropology (Neumann 1998, 1-37) - disciplines predicated on 'single-society' models of social and cultural change (Rosenberg 2016a).

In recent decades, the problem of internalism has become the object of intense criticism: the rise of postcolonial theory, in particular, has served to thematise the 'colonial encounter' as a historically-generative experience of

\footnotetext{
${ }^{1}$ In this connection, it is notable that Lévi-Strauss's $(1963,363-365)$ account of 'The Particular Task of Anthropology' - defined by its scientific method of comparison, its conceptions of 'totality' and 'system', and its investigation of 'non-civilised' or 'non-industrial' societies proceeds without any discussion of the interactive social and cultural relations which characterised the colonial origins of anthropological thought (cf. Steinmetz 2007).
} 
inter-cultural transformation and intellectual production (Bhabha 1994; Said 2003). The central thrust of this scholarship highlights the necessity of a properly intersocietal form of social theory and international studies - one that would more adequately theorise the interactive coexistence of modern cultural systems, ideologies, and mentalities (Go 2012; Bhambra 2014; Murray 2019). Still, many of the most basic theoretical and methodological questions raised by this task remain significantly under-analysed. What role does the interaction between societies play in the development of cultural systems? Is there such a thing as a distinctively intersocietal dimension to the history of ideas and cultural production? What factors might comprise such a concept, and through what kinds of causal mechanisms does it operate?

In what follows, I shall address these questions through the lens of 'uneven and combined development' (UCD). In line with the aims of this Special Issue, I seek to explore the frontiers of UCD by applying its core premises to an area of inquiry that has been somewhat neglected in the existing literature: the dynamics of cultural development - meaning cumulative change in the socially shared ideas, identities, and symbolic systems by which historical agents understand and act upon the world (Little 2010, 198-99). While it is now properly recognised that culture represents a constitutive dimension of social structure and historical change (Kane 1991, 62ff; Steinmetz 1999, 24-26; Mahoney and Rueschemeyer 2003, 22-25; Sewell 2005, 81-174; Adams, Clemens, and Orloff 2005, 22ff), the UCD scholarship has recently begun to address questions of cultural transformation (Anievas and Nişancioğlu 2015; Davidson 2019; Christie and Degirmencioglu 2019), and the theory's contribution to the study of collective identities and meaning systems therefore remains underspecified. Indeed, although a number of studies highlight the empirical significance of cultural and ideational processes (see, especially, Shilliam 2009a, 15-19; 2009b, 77ff; Cooper 2015, 482-83, 485-87; Deckard et al. 2015, 6; Anievas and Nişancioğlu 2015, 111-15, 122-28, 159-60; Davidson 2019, 179-80, 193-94), this literature has not systematically theorised the cultural dimension of UCD as a historical process, with the most extensive theoretical applications of the idea concentrated on economic and geopolitical dynamics (Rosenberg 2013a; Anievas 2014).This range of focus clearly reflects the theory's origins in Trotsky's account of the differentiated 'tendencies of world development' under capitalism (Trotsky [1928] 1996, 41-45; [1932] 2017, 4-6). However - it is necessary to emphasise - the very idea of UCD represents a substantial revision to the classical theses of historical materialism, rather than an uncritical defence of them (Rosenberg 2019). Its central categories - multiplicity, unevenness, interaction and combination - reconceptualise social change as inherently multi-linear and intersocietal, grounding an internationallyoriented conception of historical development that was critically absent from the categories of classical Marxism (Rosenberg 2016a; also, Berki 1971; Davenport 2013).

In this respect, UCD's theoretical implications may reach significantly beyond its local applications in the field of socioeconomic and geopolitical analysis (pace Ashman 2009; Davidson 2009; Rioux 2015). Indeed, since the general thrust of UCD is to recover the significance of 'the international' as a dimension of historical causality, its conceptual architecture arguably entails the possibility of a properly intersocietal conception of sociocultural 
development - one that would systematically address the problems of internalism highlighted by existing critiques of methodological nationalism and Eurocentrism (cf. Go 2012; Matin 2013). This potential can be grasped if one considers the underlying premises of UCD as a social theory:

1. The social world is constitutively uneven: it is comprised of a multiplicity of societies differentiated by their experiences and levels of social development of all kinds (economic, military, cultural, and so on).

2. The coexistence of societies entails their interaction: the intersocietal character of the social world gives rises to a multiplicity of forms of combined development.

3. The combined nature of societies is a central feature of their development: the patterns of world history cannot be understood without incorporating the interactional logics that comprise international/intersocietal relations (Rosenberg 2016b).

In the next section of the article, I present this set of ontological and methodological premises as a basis for overcoming the problems of methodological internalism in sociocultural analysis. In particular, I suggest that the central categories of UCD can help identify the intersocietal causal mechanisms of cultural development: the ways in which the coexistence of unevenly developing societies creates a range of pressures, influences, and existential circumstances that shape the production of socially shared ideas. If this claim holds, it follows that within the conceptual architecture of UCD lies a genuinely 'global historical sociology' (Go and Lawson 2017) focused on the interactional formation of societies and cultures across space and time.

The theoretical foundations of this argument are concretely elaborated through a historical study of modern geocultures. Specifically, I shall analyse the emergence of 'the West' as a distinct principle of collective identification and cultural signification during the late-nineteenth and early-twentieth century era of the New Imperialism, ca. 1880-1914. While the wider lineages of this Occidentalist cultural discourse can be traced to earlier historical periods - especially the processes of conquest and settler colonialism which marked European expansion in the Americas (Todorov 1999; Anghie 2005; Bowden 2009) - a wide range of historical scholarship locates the first sustained expressions of a discrete conception of 'the West' in the late-nineteenth century (Aydin 2007, 40; Bonnett 2017, 11, 14-39; Buzan and Lawson 2015, 118-24; C. GoGwilt 1998, 220-26; Jackson 2006, 72-111; Osterhammel 2014, 86-87; Zarakol 2011, 47-48). ${ }^{2}$

Drawing on the core premises of UCD, I propose a theory of geocultural feedback to explain this process of transition, historicise the language of Western civilisation, and locate the global and geopolitical sources of modern geocultural development. On this basis, I rethink the historical formation of Western discourses and identities as a global social process rooted in the highly uneven power structures of an emergent world economy and colonial

\footnotetext{
${ }^{2}$ For reasons of style, the remainder of this article generally uses terms like 'the West' and 'Western civilisation' without quotation marks. However, this should not detract from the fact that these are historically constructed categories rather than objective social or geographic identities.
} 
international order. This theorisation is intended to locate the sources of modern Occidentalism in a particular conjuncture of global unevenness: how the onset of catch-up modernisation in late-industrialising societies like Russia and Japan (cf. Gerschenkron 1962, 42-44; Skocpol 1979, 19-23), served to undermine existing conceptions of white, European supremacy, and thereby promote a novel discourse of civilisational closure centred on the putative defence of the West. This distinctively globalised experience of combined development, I argue, brought into being a newly conceived discourse of imperilled Western supremacy which reshaped prevailing conceptions of social identity and geopolitical organisation. Against the perceived dangers of a parallel 'Eastern' modernisation, the notion of an exalted Western civilisation came to be viewed as a meaningful locus of racial solidarity and collective identification, as many Europeans and North Americans sought affective categories adequate to the changing organisation of world development. It was in and through this process of geocultural feedback that the language of Westernisation was imported from the discourse of historical backwardness forged by modernising Asian intellectuals (Aydin 2007), and transmuted into an imperialist politics of civilisational closure ranged against the growing power of 'the East.' As I shall illustrate in the third section of the article, the late-nineteenth and early-twentieth century discourse of the defence of the West is best understood as part of a global conjuncture of unevenness, forged in a conscious, if distorted, relation to rival forms of societal modernisation.

Although its focus is historical, this argument has a broader contemporary resonance. Today 'the defence of Western civilisation' has re-emerged as a major component of neo-conservative ideology (Wertheim 2017). Echoing the conceptions of civilisational decline and white supremacy which spawned the first ideologies of Western civilisation (Drolet and Williams 2018), this ideological movement has come to play a central role in the cultural production of combined development. In this frame, the structural rebalancing of the world economy from 'West' to 'East' is invested with a higher symbolic significance, fostering the polarisations of race and nationality that drive contemporary politics (Brubaker 2017). The contemporary global conjuncture is of course radically different from the late-nineteenth century, and yet, once more, the dynamics of uneven and combined development - the juxtaposition of China's rapid industrial take-off with the downturn of neoliberal capitalism in the West - have played a key role in shaping the dominant ideological cleavages of the time (Rosenberg and Boyle 2019). As such, geocultural feedback can be understood as a generalisable mechanism of cultural transformation whereby the existential conditions of unevenness unlock new ideological pathways centred on essentialist representations of societal difference.

\section{Culture and unevenness}

But why should an engagement with 'uneven and combined development' help to theorise the dynamics of cultural change? Trotsky, of course, coined the idea to capture the differential temporalities of capitalist modernisation: the peculiar asymmetries of world development, which had led Russian society to conjoin an 'advanced' industrial economy with a seemingly archaic, semi-feudal state structure (Trotsky [1932] 2017, 5). And, while he was explicit 
that Russia's peculiar experience of combined development had been formed 'under the influence and pressure of the higher culture from the West' (Trotsky [1932] 2017, 334), Trotsky often wrote as if industrial capitalism were a kind of unmediated creator of the social world. 'Industrialization,' on this view, 'is the driving force of the whole of modern culture and by this token the only conceivable basis for socialism' (Trotsky 1969, 145). Given this staunch materialism, it is perhaps unsurprising that there have been relatively few attempts to grapple with the cultural dimensions of unevenness. Indeed, UCD's critics have tended to label it a kind of economic reductionism blind to the significance of culture and ideas (Hobson 2007, 2016). What, then, is its relevance for the study of cultural change? An initial answer to this question, I suggest, can be found in Trotsky's own account of the nineteenth-century experience of 'comparative backwardness:' the widely-felt imbalances of power and prestige which led many Asian and Eastern European intellectuals to identify the West as a culturally and geopolitically coherent reality.

\subsection{The crucible of backwardness: from ucd to the idea of the west}

Among the central themes of Trotsky's analysis of Russian history is the developmental contrast between 'advanced' and 'backward' social formations (Trotsky [1932] 2017,4). Like other intellectuals engaged with the problematic of late-development (Selwyn 2011; Shilliam 2009a), he viewed the experience of relative backwardness as a generative historical condition: a 'whip of external necessity' which compelled political and economic actors to 'follow after' more powerful competitors; and yet, at the same time, a strange historical 'privilege,' given that late-comers could accelerate and modify their own developmental trajectories by assimilating 'the material and intellectual conquests of the advanced countries' (Trotsky [1932] 2017, 4-5). The central thrust of this analysis was that, viewed internationally, Russian social development had been fundamentally conditioned by the presence of the more powerful industrial societies of the West. 'Under the influence and the pressure of its more differentiated Western milieu,' Russian absolutism had been forced to confront the military and economic advantages which accrued to the first major powers of industrial capitalism: Britain, France, Germany and the USA (Trotsky 1969, 41, 50-51). This was why, in Russia, the experience of relative backwardness was such an acutely transformative condition. It was how an autocratic Czarist state had come to act as the agent of capitalist modernisation, establishing the preconditions for a socialist revolution in a still semi-feudal society (Rosenberg 2019).

At a deeper theoretical level, the social foundations of this process - the perceptions of societal difference engendered by a historic global power imbalance derived from the condition of spatio-temporal 'unevenness,' which Trotsky conceived as the 'most general law of the historic process' (Trotsky [1932] 2017, 5). The dialectical relationship between 'advanced' and 'backward' developmental spheres opens out, in Trotsky's writings, on to a broader proposition about the texture of historical development in general. Specifically: it underscores the centrality of historical unevenness to human social life, that is, the idea that the social world 'contains not one but many societies' - a multiplicity of social formations of different kinds and scales, marked by distinct identities and institutional forms, all developing at different tempos (Rosenberg 2016b, 16). The implications of this 
premise are far-reaching, and other writers have demonstrated its implications for processes of capitalist expansion and social revolution which animated Trotsky's theory of history (Anievas and Nişancioğlu 2015; Matin 2007). Yet the category of unevenness not only pertains to the dynamics of economic and political development; it also implies that the existential and intellectual circumstances of human social life exist within a wider interactive context, made up of the coexistence of multiple societies; and this, in turn, suggests that the process of cultural development must also be subject to a range of internationally-generated, 'non-internalist', causal and constitutive dynamics (Rosenberg 2016b, 135-41).

This formulation might appear abstract, but an initial picture of its concrete implications can be found in Trotsky's depiction of Russia's distinctive idea of the West. 'Russian thought,' he wrote in a 1906 reflection on the problem of national backwardness, 'developed under the direct pressure of the higher thought and more developed economies of the West' (Trotsky 1969, 41-42). The process of uneven development dictated by Russia's 'external social-historical milieu' had not only compelled the Czarist autocracy to adopt the most advanced systems of economic and military power (Trotsky 1969, 38); the comparative example of a seemingly 'higher culture from the West' had also engendered an internal cultural opposition between 'Slavophilism and Westernism' that expressed the central dilemma of nineteenth-century Russian society (Trotsky [1932] 2017, 333-34). For Trotsky, the underlying terms of these discursive positions and identities, it can be inferred, derived centrally from the opposition between traditionalist and modernist strategies of national developmentalism. For the ethos of 'Slavophilism' - the 'messianism of backwardness' - was a direct ideological inversion of the Muscovite strategy of 'Europeanization' associated with the era of Peter the Great. To the challenge of historical backwardness, the Slavophiles offered a neo-traditionalist project of Russian nativism that sought to resolve the crisis of Czarism through the inner resources of 'the people' and 'the Church' (Trotsky [1932] 2017, 5-6). Thus, shaped by the influencing pressure of a more advanced order of Western powers, Russian society gestated a deep cultural fissure around the problem of modernisation. The experience of historical unevenness - the juxtaposition of development with underdevelopment, Russian society with its perceptibly more powerful military-industrial rivals - had shaped its very categories of cultural understanding and identity - 'Slavophiles' and 'Westerners', 'Muscovite' and 'Asiatic' (Trotsky [1932] 2017, 5-6).

In this way, it can be argued, the UCD formula builds a conception of the international - the interactive coexistence of societies - into a general logic of cultural development. For at its core, the idea provides an extended meditation on the consequences of societal multiplicity for human social life as such. Indeed, there is a deep logic of intersocietal causality running through Trotsky's whole account of the Russian transition: the geopolitical and economic power differentials that constituted Czarism's specific international environment; the self-consciousness of comparative backwardness which followed from these structural imbalances; the ensuing divide between Slavophilism and Westernism as contending solutions to the crisis of absolutism; the rapid and state-directed process of industrial transformation which followed from developmental pressures and opportunities of Russia's unique geopolitical position; and, finally, the emergence of an advanced socialist and 
artistic culture which, drawing on the tradition of European Marxism, outmatched many of the intellectual achievements of the West. All these dynamics arise fundamentally from the intersocietal character of 'world development' (Trotsky [1928] 1996, 66). And, as Trotsky's reflections on the origins of the Westerner-Slavophile divide imply, this internationally-generated process of uneven and combined development was marked by its own distinctive cultural logic: the tensions between 'modernity' and 'tradition' that emerged from the crucible of Russian backwardness. As we shall see, this dichotomy was in many ways a general feature of the intensification of global unevenness during the nineteenth century.

There is thus every reason to try and recover the language of UCD from the kind of economic reductionism sometimes associated with it. For, in contrast to the internalist theoretical schemas conceived by Weber, Durkheim and Lèvi-Strauss, Trotsky's categories of unevenness and combination contain within them a profound argument about the intersocietal logic of cultural change and subjectivity.

\subsection{Geocultural feedback}

The foregoing discussion has presented the UCD vocabulary as a resolution to the problem of methodological internalism. Yet it does not tell us how this potential can be generalised as a theory of sociocultural change. Before outlining the historical constitution of nineteenth-century Occidentalism, I shall therefore sketch three constitutive dimensions of uneven and combined development as a cultural process. I thereby propose an understanding of geocultural feedback as an historically constituted and dynamic expression of UCD in the field of 'culture.' This formulation attempts to emphasise the generative international context of historical development in a way that better incorporates the cultural dimension of social life. Its basic tenets can be categorised under the rubrics of identity, temporality, and mutation. More concretely: through this discussion, I develop my argument about the historical construction of the West as a modern social form.

2.2.1. Multiplicity and identity. The notion of historical unevenness registers the coexistence of multiple societies: the fact that the social world comprises a multiplicity of social entities of different kinds (Rosenberg 2013b, 582). This feature of social existence eludes internalist conceptions of cultural development, but, in the vocabulary of UCD, the categories of unevenness and combination signify the inherently relational character of social existence. A conception of the social world as both multiple and uneven therefore builds a conception of cultural relationality into its core theoretical optic. It encompasses the idea of identity as an inherently relational phenomenon constituted by the interactions between one social actor or group and another (Matin 2020). It locates the possibility of collective identity-formation in the constitutive interface between multiple social entities and differentially constituted cultural subjectivities. Inherent to the unevenness of the social world is the capacity for social actors to identify themselves and others in relation to social difference - 'otherness.' The nineteenth-century discourse of essential 
'Eastern' and 'Western' civilisations reflects this deep structural condition in historically and ideologically specific terms. It signifies the symbolic and cultural dimensions of unevenness as a lived historical reality.

In concrete terms, these dimensions of historical unevenness are registered in a vast literature on collective identity-formation. Arguably, both constructivist (Neumann 1996) and postcolonial (Said 2003) approaches capture exactly this relational dynamic of self- identification vis-à-vis social multiplicity. For the fact that social agents can identify themselves according to national, ethnic, civilisational or other identity categories reflects the persistence of difference and variation as enduring features of social life. However, by locating the sources of this sociocultural dynamic at the level of historical unevenness, the vocabulary of UCD situates the problem of identity-formation within a broader conception of societal development. It thus serves to locate the representational grammar of cultural difference - race, nation, civilisation, and so on - within a deeper understanding of the social processes and historical transformations which render such categorisations of cultural difference into viable principles of 'vision and division' (Bourdieu 1985). In contrast to the claims of poststructuralist and constructivist theorisations, for example, the nineteenth-century discourse of a universal Western civilisation cannot be grasped simply as an 'unintended' 'rhetorical commonplace,' 'tossed up by a general mutation in discourse' (pace Jackson 2006, 73-74; cf. Hellmann and Herborth 2017; Vuorelma 2019). Instead, Occidentalist discourse works in and through the racial and civilisational categorisations of differential development which accompanied the long-nineteenth century rise of a deeply uneven and empire-centred world economy (Kaiwar and Mazumdar 2003, 264). Its historical force testifies less to the arbitrariness of geocultural representations than to the phenomenological experience of relative backwardness and its correlatives - catch-up development, competitive modernisation, the presence of contending developmental temporalities. The specific metageography of Occidentalism - epitomised by Yukichi Fukuzawa's hierarchy of 'barbarism, semi-Enlightenment, and civilisation' (Conrad 2012, 1019) — bears an integral relationship to the division between 'industrialised, industrialising, [and] pre-industrial regions' that emerged from the staggered expansion of modern capitalism (Rosenberg and Boyle 2019, 36).

2.2.2. The simultaneity of the non-simultaneous. A central implication of the 'law of unevenness' (Trotsky [1932] 2017, 5) is that there can be no single pattern of historical development. 'History does not repeat itself' (Trotsky 1969, 52): the coexistence of differentially developing societies means that social change operates through logics of interaction and combination whereby the transfer of resources, ideas, and technologies from one society to another produce inherently multi-linear historical trajectories (Rosenberg 2016a, 137). Trotsky used this schema to explain how, in nineteenth-century Russia, the external influence of Western capitalism had fostered the unique combination of developmental forms which had led a semi-feudal absolutist state to inadvertently create the basis for proletarian revolution. More generally, the logic of combined development registers the differentiated character of historical temporality: the intersection between 'native' and 'foreign,' 'modern' and 'archaic,' 'the simultaneity of the non-simultaneous' (Bloch 1977). This conception of 
combined unevenness provides a critical route into the production and transformation of cultural forms. Against the logic of national and civilisational exceptionalisms, it draws attention to processes of intellectual exchange, crosscultural comparison, mimesis and knowledge transfer as potentially recurrent mechanisms of cultural development. In these terms, the nineteenth-century proliferation of Westernisation discourses - especially in societies such as Russia and Japan - hinged on the perceived necessity of emulating the most advanced forms of economic and military technology in order to overcome the power and status differentials inscribed in the emergent international order (Osterhammel 2014, 912). They register a widely-felt experience of temporal disjunction: the need to transcend 'traditional' social orders by catching up with the forerunners of capitalist modernity.

2.2.3. The dynamics of geocultural feedback. The larger point here is that the UCD vocabulary suggests a specifically international conception of cultural development as an intersocietal, multilinear, and interactive historical process. This dialectical conception of cultural change responds to the problem of methodological internalism by incorporating the condition of internationality into its core theoretic categories. Through the historical analysis sketched below, I find a broader expression of the process of uneven and combined development in the dynamics of geocultural feedback through which putatively 'Western' and 'non-Western' societies engaged in mutually transformative processes of selfdefinition, social restructuring, and intellectual innovation. As conceptualised here, geocultural feedback was the symbolic and ideological counterpart to the long-nineteenth century intensification of global unevenness. In this context, the increasingly dense interactions between unevenly developed societies helped engender novel imaginings of Western civilisation through an intrinsically intersocietal causal process. Over the course of the nineteenth century, the experience of relative backwardness in late-industrialising societies began to translate into self-consciously Westernising projects of catch-up development, which aimed at shifting the global distribution of modern geopolitical and economic power, and undermined prevailing conceptions of European cultural supremacy. The feedback-effect of these 'Eastern' projects of self-strengthening and social modernisation, epitomised by the self-strengthening efforts of latenineteenth century Russia and Japan, gradually shaped a reactive discourse of civilisational closure centred on the West's struggle against a rising force of geostrategic and racial challengers, manifesting the emergent conjuncture of uneven and combined development in a novel cultural form.

\section{Occidentalism in the history of uneven and combined development}

It now comes to reconstruct the pathways of historical transformation and cultural change that have been hinted at so far. To this end, I shall first examine how the idea of Western civilisation figured in nineteenth-century debates about the problem of relative backwardness, before illustrating the reactive politics of civilisational closure which began to crystallise the discourse of an imperilled West during the fin-de-siècle era of the New Imperialism. 


\subsection{Unevenness: the origins of 'westernisation'}

The intense opposition between 'Westernism' and 'Slavophilism' that marked Trotsky's diagnosis of Russian historical development may seem peculiar and idiosyncratic. Yet a wide range of historical scholarship (GoGwilt 1998, 226ff; Heller 2006, 150; Osterhammel 2014, 616, 912-13; Makdisi 2014, xv; Aydin 2007, 3), and social science (Zarakol 2011, 42-49; Buzan and Lawson 2015, 25-28), suggests that exactly this equation between 'Westernisation' and 'modernity' was a general feature of nineteenth-century cultural change especially in those societies where the experience of relative backwardness was most acute. In particular, it is now clear that East Asian, Ottoman, and Russian intellectual production played a key role in fostering the logics inter-cultural comparison that helped the transform the West into a standard frame of reference (Bonnett 2017, 63-122; Carrier 1995; Duara 2001; Esenbel 2004). Among the most important works of this kind, Aydin's (2007) study of Pan-Islamic and Pan-Asian thought demonstrates that the idea of a distinctively Occidental mode of social and political organisation was initially the creation of mid-nineteenth century Asian intellectuals, whose interest in the imagined West arose from a shared, post-Enlightenment project of progressive social transformation (Aydin 2007, 21-37). With the intensification of European imperialism after c.1880, such positive conceptions of Western culture were gradually inverted, as both Japanese and Ottoman nationalists began to view 'European-modelled modernisation projects' as an urgent geopolitical imperative (Aydin 2007, 73-77, 104).

Influential Japanese academic Fukuzawa Yukichi (1835-1901), for example, argued that 'backward-looking' societies would be condemned to colonisation if they failed to adopt Western models of social development (Bonnett 2005, 512). Even more strikingly, Yukichi's 1885 essay on 'De-Asianization' emphasised that 'our country cannot afford to wait for the enlightenment of our neighbours and to co-operate in building Asia up. Rather, we should leave their ranks to join the camp of the civilised countries of the West.' Therefore, he asserted, Japan should treat its Chinese and Korean neighbours 'as the Westerners do' (cited in: Conrad 2012, 1022). It was this reaction against relative backwardness, epitomised by the competitive emulation of Western models, that set Japan on route to an aggressive strategy of imperial expansion in the aftermath of the Meiji Restoration (Peattie 1984, 94-94; Shimazu 2008, 161ff; Tsuzuki 2000, ch.6). While this process set Russia and Japan on a course for war in 1904-5, it reflected the same perceptions of national backwardness that had been articulated in the 'Westerner-Slavophile' debate of the early-nineteenth century.

Across the world, the themes of 'Westernisation' and 'relative backwardness' thus evolved together, shaping a novel opposition between 'traditionalists' whether Russian Slavophiles or orthodox Confucians - and 'modernisers' (Osterhammel 2014, 93, 188, 625-28). The reverberations of this movement were widely-felt across Europe and the United States, where the idea of a backward yet gradually ascending 'East' became an increasingly central theme of political discourse as the nineteenth century progressed (Adamovsky 2005; Bavaj 2011). As GoGwilt's (1995) seminal genealogy of Western discourse makes clear, it was only in the period after c.1870 -i.e. when the competitive thrust of 'Eastern' catch-up development was just beginning to emerge - that European and 
North American intellectuals began to converge around a shared sense of the West as a coherent cultural reality (GoGwilt 1995, 47ff). Among the central markers of this discourse was the proliferation of 'decline-and-fall' accounts of Western civilisation, made famous by Oswald Spengler, and typical among the intellectual milieu of the 1890s and 1900s (GoGwilt 1995, 54; Heller 2006, 273). In the words of the influential American naval strategist Alfred Thayer Mahan, a 'new and significant restlessness' was emerging 'among the Oriental peoples, aroused at length, by intimate contact with Europeans, from the torpor and changelessness of ages;' the 'new era of colonization' was thus marked by a growing confrontation between 'the East and the West' (Mahan 1902a, 31; 1902b, 217).

Now, for the first, time the organisation of the globe could be described through a series of metaphorical distinctions, famously recorded by Rudyard Kipling, whose abstractions articulated a new sense of geopolitical division 'East is East and West is West,' 'Somewhere East of Suez,' 'the white man's burden' (GoGwilt 1995, 2000, 89, 143). These formulations, it should be emphasised, drew on a distinctively late nineteenth-century worldview suffused by the emergent discourses of Social Darwinism and 'race science' (Hung 2003, 268-74). The hierarchical conceptions of cultural difference associated with modern Occidentalism (Coronil 1996, 56-57) thus crystallised around the themes of civilisational decline and racial-geopolitical competition. In the words of Charles Pearson, a key architect of Anglo-American anti-Japanese propaganda (Hobson 2012, 87ff), 'the day was probably not far distant when we would see the races of our Western civilisation ... in a large measure superseded by the yellow races of the world' (Jones 2001, 95). This, for example, was how Theodore Roosevelt, a frequent correspondent of Kipling and his British-imperial milieu (Dyer 1992), characterised the civilisational order of the early-twentieth century:

The lines of development of these two civilisations, of the Orient and the Occident, have been separate and divergent since thousands of years before the Christian era... An effort to mix together, out of hand, the peoples representing the culminating points of two such lines of divergent cultural development would be fraught with peril (Roosevelt 1914, 306).

In all of these cases, the notion of the West helped historical actors to think in global terms about the problems of comparative backwardness generated by an unprecedented concentration of power in North Western Europe and North America (Buzan and Lawson 2015, 176). Absent from eighteenth-century representations of Asia and Eastern Europe, such as those produced in the context of the Scottish Enlightenment or the European Romanticism (Adamovsky 2005; P. Dodds 2018, 60; Hung 2003; Makdisi 1998), the West could now be figured as the universal standard of modernity within a profoundly uneven international order (Zarakol 2011, 91). While earlier forms of European colonialism had, of course, gestated their own ideologies of civilisational and cultural supremacy, this nineteenth-century discourse of Westernisation rested on a configuration of global power which had not existed prior to the post-1800 era.

More specifically, forged in a conscious relation to the rising power of the East,' the self-valorising discourse of Western civilisation was replete with anxious references to the threat of racial and geopolitical counter-powers. Its distinctiveness not only derives from the newly conceived image of a 
homogenous Western world, but from the ways in which this imagined geopolitical sphere was now envisaged as the site and object of strategic competition and cultural crisis. It was in these defensive terms that Oswald Spengler, the fin-de-siecle's most famous Westerniser, characterised the Bolshevik Revolution as an alien threat to West. Drawing explicitly on the Slavophile conception of a native Russian instinct, Spengler developed an Orientalist construction of 'Mother Russia' as a direct counterpoint to Western civilisation:

The word 'Europe' ought to be struck out of history. There is historically no 'European' type... It is thanks to this word 'Europe' alone, and the complex of ideas resulting from it, that our historical consciousness has come to link Russia with the West in an utterly baseless unity - a mere abstraction derived from the reading of books - that has led to immense real consequences. In the shape of Peter the Great, this word has falsified the historical tendencies of a primitive human mass for two centuries, whereas the Russian instinct has very truly and fundamentally divided 'Europe' from 'Mother Russia' with the hostility that we can see embodied in Tolstoi, Aksakov, or Dostoyevsky. 'East' and 'West' are notions that contain real history, whereas 'Europe' is an empty sound (cited in GoGwilt, 1995, 50).

In a major world-historical irony, even the most self-consciously internalist conception of Western civilisation turns out to be a kind of imported cultural hybrid, indebted to the 'Slavophile-Westerner' debate of the early-nineteenth century. This point should be emphasised: the image of the West is historically conditioned, determined, and brought into being by the influence and pressure of its external milieu.

\subsection{Combination: the rise of civilisational imperialism}

With Spengler's 'West,' we find a very different cultural universe to that of the early-nineteenth century. Published in two volumes between 1918 and 1922, The Decline of the West appeared in the aftermath of the First World War and the decades of global imperialism which preceded it. In a time of growing class and geopolitical antagonism, the universalistic worldviews of earlier liberal and romanticist political cultures had been increasingly superseded by an ideological amalgam of Social Darwinism, white supremacy, and expansionist geopolitics (Anderson 2002, 12; Mommsen 1990, 210-26). These were essentially ideologies of imperial competition, fixated on the rivalry between nations, races and civilisational groupings - Slavic, Asiatic, Anglo-Saxon and so on (Hobson 2012, 106ff; Heffernan 2000, 27-51; Geulen 2007, 70-78; Bayly 2004, 462-67). Spengler crystallised a conception of Western civilisation which had been evolving since the 1880s (GoGwilt 1995, 44).

Among the most influential figures in this Occidentalist turn was the British sociologist Benjamin Kidd. His 1894 work Social Evolution cast the expansion of 'Western civilisation' as a 'single continuous growth' culminating in the 'absolutely unique' intellectual achievements of the 'Western races' during the European 'Renaissance' (Kidd 1894, 147, 186). The centrality of scientific racism to this formula was clear in Kidd's view of the 'Anglo-Saxon races' as a uniquely 'progressive peoples' characterised by their superior energy, virility and ingenuity (Kidd 1894, 55-56). This social-Darwinian perspective located the sources of Western 'progress' in the 'the rivalry of life' which 
European and North American forms of social organisation had allowed to rise to 'the highest possible degree of efficiency (Kidd 1894, 142). In the 'Eastern' world, by contrast, the stultifying institutions of caste and despotism had prevented such competitive urges from achieving their natural dynamism:

In Eastern countries where the institution of caste still prevails, we have, indeed, only an example of a condition of society in which (in the absence of that developmental force which we shall have to observe at work amongst ourselves) these groups and classes have become fixed and rigid, and in which, consequently, progress has been thwarted and impeded at every turn by innumerable barriers which have for ages prevented that free conflict of forces with the community which has made so powerfully for progress among the Western peoples (Kidd 1894, 142).

In parallel, the Oxford-based Indologist Friedrich Max Müller deployed the evolutionary paradigm as a replacement for older Orientalist theories of comparative religion, emphasising the essential backwardness of all non-European cultures (Hung 2003, 269). This Occidentalist schema located the 'complete break between East and West' in the cultural divisions of the prehistoric period, and emphasised the essential contrast between 'the white and dark men, the Aryan and the Semite' (Müller 1893, 8-9). In a similar vein to Kidd's Anglo-Saxonism, Müller $(1893,36)$ celebrated the thousands of Englishmen ruling the millions of human beings in India, in Africa, in the Americas, and in Australasia' - an achievement which had 'more than realised the dream of Alexander, the marriage of the East and the West.'

However, such fantasies of 'Western' civilisational supremacy were predicated on an inherently unstable assumption of permanent 'Eastern' backwardness. As previously argued, the original 'Eastern' conception of 'Westernisation' was centrally a modernising discourse of catch-up developmentalism. In a world of uneven and combined development, where societies could leverage the achievements of more 'advanced countries' to 'make leaps' 'under the whip of external necessity' (Trotsky [1932] 2017, 5), the power imbalances which divided 'East' from 'West' were potentially reversible. Thus, underlying the fin-de-siecle discourse of Western supremacy, we find a latent series of anxieties about social decadence and civilisational decline. This discourse, as Dirk Bönker's (2016) study of American naval strategy suggests, had a hard geopolitical dimension rooted in the strategic challenge of both Russian and Japanese expansionism (Bönker 2016, 33-46, 90-91, 117, 240ff). Typical of this outlook was the argument of US Rear-Admiral Bradley Fiske that the imitation of advanced industrial and military techniques by states like Imperial Japan was generating an increasingly competitive international environment - and thus, with the 'opening of undeveloped countries,' the expansion of world trade was producing 'a stupendous competition involving, in a vast and complicated net, every red blooded nation of the earth' (Fiske 1911, 706, 709).

Echoing these concerns about Japanese-style catch-up development, Alfred Thayer Mahan warned that 'Europe civilisation' would 'not survive' if it failed to sustain its competitive edge over the barbarian world:

In this our day, the development of the world may be said to present two principal factors: European civilisation, and the civilisations, or barbarisms, as the case may be, which are not European in origin... In the future processes of adjustment, in which we doubtless shall see the superior organisation of 
European civilisation imitated as it has been successfully in Japan, it is of the first importance that the European family of states retain in full the power of national self-assertion, of which the sentiment of nationality is the spirit and armaments the embodiment (Mahan 1911, 8-9).

In this way, the 'occidentalizing of Japan' had exposed the civilised West to economic and strategic pressures that it would now have to contend with geopolitically (Mahan 1902a, 31).

In this context, it the idea of an imperilled Western civilisation became a major theme of conservative anxieties about social decadence (GoGwilt 1995, 53). For both these ideological motifs - decadence and declinism - articulated concerns about the erasure of imperial standing during an era of growing international competition. In response, British imperial statesmen like Arthur J. Balfour and Alfred Milner, developed protectionist conceptions of imperial federation that drew heavily on the imagined connections between 'race,' 'progress' and 'the West' (Balfour 1908, 27, 42; Milner 1909, 18,56-57, 83). The proliferation and intersection of these identity categories was a striking feature of the fin-de-siecle.

Thus, a wider explanation for the imperial ideology of Western civilisation begins to emerge. It rests on the dynamics of geocultural feedback through which nineteenth-century societies like Russia and Japan, Britain and the United States, became entwined within a broader logic of world development. This process begins with the condition of historical unevenness - the developmental power gaps fostered by the regional distribution of the first Industrial Revolution. These power differentials were the locus for a modernising discourse of Westernisation that reflected the desire of late-developing societies to overcome the problems of historical backwardness. Yet, through the resulting process of intensified, catch-up development, the comparative light of the East made it possible to envisage a future process of civilisational decline. This interpretation would explain why it was only at the turn of the nineteenth to the twentieth century, in response to the apparent dangers of 'Eastern' selfstrenghtening, that such a defensive conception of Western chauvinism became a pervasive discourse of collective identification. This shift not only reflected the external pressures imparted by the rise of a new set of global competitors. The fantasy of civilisational closure provided by Western imaginings of a static and backward East also offered an appealing prospect of geopolitical stability which promised to insulate the West from the destabilising impact of catch-up development elsewhere. It was this unstable relationship to the 'non-West' which shaped the fin-de-siecle transition toward a deeply pessimistic discourse of racial conflict and civilisational rivalry. In an effort to overcome the anxieties engendered by an increasingly unstable and multipolar geopolitical environment, many Anglo-American observers turned to a defensive discourse of the Western race's struggle to maintain the prevailing imperial order. The prospect of a radical rupture in the overall balance of geostrategic power thus set the mould for a new cultural understanding of the West, defined less by the universal goals human enlightenment than the defence of a bounded racialpolitical community:

Progress is with the West: with communities of the European type. And if their energy of development is some day to be exhausted, who can believe that there remains any external source from which it can be renewed? Where 
are the untried races competent to construct out of the ruined fragments of our civilisation a new and better habitation for the spirit of man?' (Balfour 1908, 42).

\section{Conclusion}

While it was originally coined to describe the international dynamics of capitalist development, this article has argued that, as a historical process, uneven and combined development contains a distinct cultural dimension, in which the interactive multiplicity of societies constitutes and shapes socially shared ideas and collective mentalities. By examining Trotsky's account of Russia's late-industrialisation, it has shown how this conception of cultural change can be derived from the concepts of historical unevenness and combined development that underpin the UCD vocabulary. On this basis, it has elaborated a theoretical conception of geocultural feedback which, against the wider problem of methodological internalism, can properly access the causal and constitutive dynamics of 'the international' as a major source of cultural transformation. Applied to the latenineteenth and early-twentieth century conjuncture of the New Imperialism, this theoretical perspective provides a historical-sociological explanation for the emergence of the idea of the West as a unified cultural entity: how a modernising discourse of Westernisation was first gestated in late-industrialising societies like Russia and Japan, and then subsequently transformed into a defensive discourse of civilisational closure by Anglo-American intellectuals' anxious response to the geopolitical rise of such late-developers. It is deeply ironic that the very idea of the West - a self-consciously internalist cultural ideology — should turn out to be a fundamentally intersocietal phenomenon. However, there is a striking historical parallel between the ongoing re-emergence of the language of Western civilisation within neoconservative political discourse, on the one hand, and the origins of the idea in the late-nineteenth century imperial era, on the other. Once again the destabilising consequences of uneven and combined development have engendered a defensive ideological stance centred on the putative characteristics of the West. How to think through this feature of contemporary international politics remains a politically and theoretically urgent challenge. A reworked conception of UCD as a culturally generative process represents an initial step in this larger task.

\section{Disclosure statement}

No potential conflict of interest was reported by the author.

\section{Funding}

This work was supported by the Economic and Social Research Council, Grant Number: 1508930. 


\section{Notes on contributor}

Joseph Leigh recently completed his PhD in International Relations at the LSE, where he now teaches IR and Political Science. His research interests include geopolitics, historical sociology, and international relations theory. His current work examines the international history of power politics and imperialism in the nineteenth and twentieth centuries.

\section{ORCID}

Joseph Leigh (D) http:/ / orcid.org/0000-0001-5646-489X

\section{References}

Mahan, Alfred Thayer (1902b) 'The Persian Gulf and International Relations' in Retrospect and prospect (Boston, MA: Little, Brown, and Company), 209-254

Adamovsky, Ezequiel (2005) 'Euro-orientalism and the making of the concept of Eastern Europe in France, 1810-1880', The Journal of Modern History, 77:3, 591-628

Adams, Julia, Elisabeth Stephanie Clemens, and Ann Shola Orloff (2005) 'Introduction: social theory, modernity, and the three waves of historical sociology' in Remaking modernity: Politics, history, and sociology (Durham, NC: Duke University Press), 1-72

Anderson, Perry (2002) 'Internationalism: a breviary', New Left Review, II:14, 5-25

Anghie, Antony (2005) Imperialism, sovereignty, and the making of international law (Cambridge, UK: Cambridge University Press)

Anievas, Alexander (2014) Capital, the state, and war: class conflict and geopolitics in the thirty years' crisis 1914-1945 (Ann Arbor: University of Michigan Press)

Anievas, Alexander and Kerem Nişancioglu (2015) How the west came to rule: the geopolitical origins of capitalism (London: PlutoPress)

Ashman, Sam (2009) 'Capitalism, uneven and combined development and the transhistoric', Cambridge Review of International Affairs, 22:1, 29-46

Aydin, Cemil (2007) The politics of anti-Westernism in asia: visions of world order in PanIslamic and Pan-Asian thought (New York: Columbia University Press)

Balfour, James Arthur (1908) Decadence: Henry sidgwick memorial lecture (Cambridge: Cambridge University Press)

Barkawi, Tarak, and George Lawson (2017) International origins of social and political theory vol. 32 (Bingley:Emerald Publishing Limited), 1-7. < https://doi.org/10. 1108/S0198-871920170000032001>

Bavaj, Riccardo (2011) 'The west': a conceptual exploration', Europäische Geschichte, $<$ http:/ /ieg-ego.eu/en/threads/crossroads/political-spaces/riccardo-bavaj-thewest-a-conceptual-exploration $>$

Bayly, C. A (2004) The birth of the modern world, 1780-1914 (Oxford: Blackwell)

Beck, Ulrich (2007) 'The cosmopolitan condition: why methodological nationalism fails', Theory, Culture E Society, 24:7-8, 286-290

Berki, R N (1971) 'On marxian thought and the problem of international relations', World Politics, 24:1, 80-105

Bhabha, Homi K (1994) The location of culture (London: Routledge)

Bhambra, Gurminder (2014) Connected sociologies (London: Bloomsbury Academic)

Bloch, Ernst, and Mark Ritter (1977) 'Nonsynchronism and the obligation to its dialectics (1935)', Translated by Mark Ritter, New German Critique, 11, 22-38

Bönker, Dirk (2016) Militarism in a global age: naval ambitions in Germany and the United States before world war I (Ithaca, NY: Cornell University)

Bonnett, Alastair (2005) 'Occidentalism and plural modernities: or how Fukuzawa and Tagore invented the west', Environment and Planning D: Society and Space, 23:4, 505525

Bonnett, Alastair (2017) The idea of the west: CULTURE, politics and history (Basingstoke: Macmillan International Higher Education) 
Bourdieu, Pierre (1985) 'The social space and the genesis of groups', Theory and Society, 14:6, 723-744

Bowden, Brett (2009) The empire of civilization: the evolution of an imperial idea (Chicago, IL: University of Chicago Press)

Brubaker, Rogers (2017) 'Between nationalism and civilizationism: the European populist moment in comparative perspective', Ethnic and Racial Studies, 40:8, $1191-1226$

Buzan, Barry, and George Lawson (2015) The global transformation (Cambridge: Cambridge University Press)

Carrier, James G (1995) Occidentalism: images of the west (Oxford: Oxford University Press)

Christie, James, and Nesrin Degirmencioglu (2019) Cultures of uneven and combined development: from international relations to world literature (Leiden: Brill). <http:// brill.com/view/title/34240>

Conrad, Sebastian (2012) 'Enlightenment in global history: a historiographical critique', The American Historical Review, 117:4, 999-1027

Cooper, Luke (2015) 'The international relations of the 'imagined community': explaining the late nineteenth-century genesis of the Chinese nation', Review of International Studies, 41:3, 477-501

Coronil, Fernando (1996) 'Beyond occidentalism: toward nonimperial geohistorical categories', Cultural Anthropology, 11:1, 51-87

Davenport, Andrew (2013) 'Marxism in IR: condemned to a realist fate?', European Journal of International Relations, 19:1, 27-48

Davidson, Neil (2009) 'Putting the nation back into 'the international', Cambridge Review of International Affairs, 22:1, 9-28

Davidson, Neil (2019) 'Uneven and combined development: between capitalist modernity and modernism' in Christie, James, and Nesrin Degirmencioglu (eds.) Cultures of uneven and combined development (Leiden: Brill), 167-198

Deckard, Sharae, Nicholas Lawrence, Neil Lazarus, Graeme Macdonald, Upamanyu Pablo Mukherjee, Benita Parry, and Stephen Shapiro (2015) Combined and uneven development: towards a new theory of world-literature. Warwick Research Collective (Liverpool: Liverpool University Press)

Dodds, Phil (2018) 'One Vast Empire': China, Progress, and the Scottish Enlightenment', Global Intellectual History, 3:1, 47-70

Drolet, Jean-François, and Michael C Williams (2018) 'Radical conservatism and global order: international theory and the new right', International Theory, 10:3, 285-313

Duara, Prasenjit (2001) 'The Discourse of Civilization and Pan-Asianism', Journal of World History, 12:1, 99-130

Durkheim, Émile (2008) The elementary forms of religious life. Translated by Carol Cosman (Oxford: University Press)

Dyer, Thomas G (1992) Theodore Roosevelt and the idea of race (Baton Rouge, LA: Louisiana State University Press)

Esenbel, Selçuk (2004) 'Japan's global claim to Asia and the world of Islam: transnational nationalism and world power, 1900-1945', The American Historical Review, 109:4, 1140-1170

Fiske, Bradley A (1911) 'Naval power', Proceedings of the US Naval Institute, 37, 683-736

Gerschenkron, Alexander (1962) Economic backwardness in historical perspective: a book of essays (Boston, MA: Harvard University Press)

Geulen, Christian (2007) 'The common grounds of conflict: racial visions of world order 1880-1940' in Sebastian Conrad and Dominic Sachsenmaier (eds) Competing visions of world order: Global moments and movements, 1880s-1930s (New York: Palgrave Macmillan), 69-96

Gilroy, Paul (1993) The black atlantic: modernity and double consciousness (London: Verso)

Go, Julian (2013) 'For a postcolonial sociology', Theory and Society, 42:1, 25-55

Go, Julian, and George Lawson, eds. (2017) Global historical sociology (Cambridge: Cambridge University Press)

GoGwilt, Christopher (1995) 'True west: the changing idea of the west from the 1880s to the 1902' in Silvia Federici (ed) Enduring Western civilization: the construction of the concept of Western civilization and its "others" (Westport, CT: Praeger), 37-60 
GoGwilt, Christopher (1998) The invention of the west: Joseph conrad and the DoubleMapping of Europe and empire (Stanford, CA: Stanford University Press)

GoGwilt, Christopher (2000) The fiction of geopolitics: afterimages of geopolitics, from wilkie Collins to alfred hitchcock, 1860-1940 (Stanford, CA: Stanford University Press)

Goswami, Manu (2002) 'Rethinking the modular nation form: toward a sociohistorical conception of nationalism', Comparative Studies in Society and History, 44:04, 770-799

Heffernan, Andrew (2000) 'Fin de Siècle, Fin Du Monde? On the Origins of European Geopolitics, 1890-1920' in Klaus Dodds and David Atkinson (eds) Geopolitical traditions: a century of geopolitical thought (London: Routledge), 27-51

Heller, Kathleen M (2006) 'The dawning of the west: on the genesis of a concept' (PhD dissertation, Union Institute and University)

Hellmann, Gunther, and Benjamin Herborth (2017) Uses of "the west": security and the politics of order (Cambridge: Cambridge University Press)

Hobson, John M (2007) 'Back to the future of 'one logic or two'?: Forward to the past of 'anarchy versus racist hierarchy'?', Cambridge Review of International Affairs, 20:4, $581-597$

Hobson, John M (2012) The eurocentric conception of world politics: Western international theory, 1760-2010 (Cambridge: Cambridge University Press)

Hobson, John M (2016) 'The Lacuna of capital, the state and war? The lost global history and theory of eastern agency', International Politics, 53:5, 600-617

Hung, Ho-Fung (2003) 'Orientalist knowledge and social theories: China and the European conceptions of east-west differences from 1600 to 1900', Sociological Theory, 21:3, 254-280

Jackson, Patrick Thaddeus (2006) Civilizing the enemy: German reconstruction and the invention of the west (Ann Arbor, MI: University of Michigan Press)

Jones, David Martin (2001) The image of China in Western social and political thought (New York: Palgrave)

Kaiwar, Vasant, and Sucheta Mazumdar (2003) 'Race, orient, nation in the time-space of modernity' in Sucheta Mazumdar and Vasant Kaiwar (eds) Antinomies of modernity: essays on race, orient, nation (London: Duke University Press), 261-288

Kane, Anne (1991) 'Cultural analysis in historical sociology: the analytic and concrete forms of the autonomy of the autonomy of culture', Sociological Theory, 9:1, 53-69

Kidd, Benjamin (1894) Social evolution (New York: Macmillan and Co)

Lévi-Strauss, Claude (1963) Structural anthropology. Translated by Claire Jacobson and Brooke Schoepf Grundfest (London: Basic Books, Inc)

Little, Daniel (2010) New contributions to the philosophy of history (London: Springer Netherlands)

Mahan, Alfred Thayer (1902a) 'Retrospect and prospect' in Retrospect and prospect (Boston, MA: Little, Brown, and Company), 3-35

Mahan, Alfred Thayer (1911) Armaments and arbitration, or: the place of force in the international relations of states (New York: Harper and Brothers)

Mahoney, James, and Dietrich Rueschemeyer (2003) 'Comparative historical analysis: achievements and agendas' in James Mahoney and Dietrich Rueschemeyer (eds) Comparative historical analysis in the social sciences (New York: Cambridge University Press), 3-38

Makdisi, Saree (1998) Romantic imperialism: universal empire and the culture of modernity (New York: Cambridge University Press). <http://site.ebrary.com/id/10446124>

Makdisi, Saree (2014) Making England Western: Occidentalism, race, and imperial culture (Chicago, IL: University of Chicago Press)

Matin, Kamran (2007) 'Uneven and combined development in world history: the international relations of state-formation in Premodern Iran', European Journal of International Relations, 13:3, 419-447

Matin, Kamran (2013) 'Redeeming the universal: postcolonialism and the inner life of eurocentrism', European Journal of International Relations, 19:2, 353-377

Matin, Kamran (2020) 'Deciphering the Modern Janus: societal multiplicity and nationformation', Globalizations, 17:3, 436-451

Milner, Alfred Milner (1909) Imperial unity, speeches delivered in Canada in the autumn of 1908 (London: Hodder) 
Mommsen, Wolfgang J (1990) 'The varieties of the nation state in modern history: liberal, imperialist, fascist, and contemporary notions of nation and nationality' in Michael Mann (ed) The rise and decline of the Nation-State (Oxford: Basil Blackwell), 210-226

Müller, Max Friedrich (1893) 'Inaugural address' in E. Delmark Morgan (ed) Transactions of the ninth international congress of orientalists (London: The Committee Of The Congress) vol I, 1-37. <http://archive.org/details/in.ernet.dli.2015.282447>

Murray, Christopher (2020) 'Imperial dialectics and epistemic mapping: from decolonisation to anti-eurocentric IR', European Journal of International Relations, 26: $2,419-442$

Neumann, Iver B (1996) Russia and the idea of Europe a study in identity and international relations. New International Relations (London: Routledge). <http:// www.myilibrary.com/browse/open.asp?id=32056\&entityid=https://lse.ac.uk/ idp $>$

Neumann, Iver B (1998) Uses of the other: "the east" in European identity formation (Minneapolis, MN: University of Minnesota Press)

Osterhammel, Jürgen (2014) The transformation of the world: a global history of the nineteenth century (Princeton, NJ: Princeton University Press)

Peattie, Mark R (1984) 'Japanese attitudes toward colonialism' in Ramon Hawley Myers and Mark R. Peattie (eds) The japanese colonial empire, 1895-1945 (Princeton, NJ: Princeton University Press), 8-127

Rioux, Sébastien (2015) 'Mind the (theoretical) gap: on the poverty of international relations theorising of uneven and combined development', Global Society, 29:4, 481-509

Roosevelt, Theodore (1914) Theodore Roosevelt: an autobiography (New York: The Macmillan Company)

Rosenberg, Justin (2006) 'Why is there no international historical sociology?', European Journal of International Relations, 12:3, 307-340

Rosenberg, Justin (2013a) 'Kenneth Waltz and Leon Trotsky: Anarchy in the mirror of uneven and combined development', International Politics, 50:2, 183-230

Rosenberg, Justin (2013b) 'The 'philosophical premises' of uneven and combined development', Review of International Studies, 39:3, 569-597

Rosenberg, Justin (2016a) 'International relations in the prison of political science', International Relations, 30:2, 127-153

Rosenberg, Justin (2016b) 'Uneven and combined development: 'the international' in theory and history' in Alexander Anievas and Kamran Matin (eds) Historical sociology and world history: Uneven and combined development over the longue durée (London: Rowman \& Littlefield International Ltd), 17-30

Rosenberg, Justin (2019) 'Trotsky's error: multiplicity and the secret origins of revolutionary Marxism', Globalizations, 17:3, 477-497

Rosenberg, Justin, and Chris Boyle (2019) 'Understanding 2016: China, Brexit and Trump in the history of uneven and combined development', Journal of Historical Sociology, 32:1, e32-e58

Said, Edward (2003) Orientalism (London: Penguin)

Selwyn, Ben (2011) 'Trotsky, Gerschenkron and the political economy of late capitalist development', Economy and Society, 40:3, 421-450

Sewell, William (2005) Logics of history: social theory and social transformation (Chicago, IL: University of Chicago Press)

Shilliam, Robbie (2009a) German thought and international relations: the rise and fall of a liberal project (New York: Palgrave Macmillan)

Shilliam, Robbie (2009b) 'The atlantic as a vector of uneven and combined development', Cambridge Review of International Affairs, 22:1, 69-88

Shimazu, Naoko (2008) Japanese society at war: death, memory and the Russo-Japanese war (New York: Cambridge University Press)

Skocpol, Theda (1979) States and social revolutions: a comparative analysis of France, Russia and China (Cambridge: Cambridge University Press)

Steinmetz, George (1999) 'Introduction: culture and the state' in George Steinmetz (ed) State/culture: state-formation after the cultural turn (Ithaca, NY: Cornell University Press), 1-49 
Steinmetz, George (2007) The devil's handwriting: Precoloniality and the german colonial state in qingdao, Samoa, and Southwest Africa (Chicago, IL: University of Chicago Press)

Tenbruck, Friedrich (1994) 'Internal history of society or universal history?', Theory, Culture E Society, 11:1, 75-93

Todorov, Tzvetan (1999) The conquest of america: the question of the other (Norman, OK: University of Oklahoma Press)

Trotsky, Leon [1928] 1996. The third international after Lenin. Translated by John G. Wright (New York: Pathfinder)

Trotsky, Leon [1932] 2017. History of the Russian revolution. Translated by Max Eastman (London: Penguin)

Trotsky, Leon (1969) The permanent revolution and results and prospects. Translated by Brian Pearse. 3rd ed. (New York: Pathfinder)

Tsuzuki, Chushichi (2000) The pursuit of power in modern Japan 1825-1995 (Oxford: Oxford University Press)

Vuorelma, Johanna (2019) 'The ironic western self: radical and conservative irony in the 'Losing Turkey' narrative', Millennium: Journal of International Studies, 47:2, 190-209

Weber, Max (1991) From max weber: essays in sociology. Edited by C. Wright Mills and H. H Gerth (London: Routledge)

Wertheim, Stephen. 2017. 'Donald Trump's plan to save western civilization', The New York Times, 22 July, sec. Opinion. <https://www.nytimes.com/2017/07/22/ opinion/sunday/donald-trumps-plan-to-save-western-civilization.html $>$

Wimmer, Andreas, and Nina Glick Schiller (2003) 'Methodological nationalism, the social sciences, and the study of migration: an essay in historical epistemology', The International Migration Review, 37:3, 576-610

Yukichi, Fukuzawa [1885] 2015. 'Goodbye Asia' in David J. Lu (ed.) Japan: a documentary history: Vol 2: the late tokugawa period to the present: a documentary history (London: Routledge), 351-353

Zarakol, Ayse (2011) After defeat: how the east learned to live with the west (New York: Cambridge University Press) 